\title{
Morphological Characteristics and Haematological Studies in Wistar Rats Subjected to Prolonged Treatment of Chloramphenicol
}

\author{
Características Morfológicas y Estudios Hematológicos en Ratas Wistar \\ Sometidas a un Tratamiento Prolongado con Cloranfenicol
}

Matthew Olugbenga Oyeyemi \& Deborah Adejoke Adeniji

OYEYEMI, M. O. \& ADENIJI, D. A. Morphological characteristics and haematological studies in Wistar rats subjected to prolonged treatment of chloramphenicol. Int. J. Morphol., 27(1):7-11, 2009.

SUMMARY: The morphological characteristics and haematological studies were studied in fifteen male albino rats (Wistar Strain) aged between 12 and 14 weeks and with a body weight of $150-180 \mathrm{~g}$. The rats were allowed to feed on commercially prepared rat pellet and provided with fresh water ad libitum. The rats were divided into three groups; the rats were in groups $\mathrm{A}, \mathrm{B}$ and $\mathrm{C}$ of 5 rats each. Group A served as control of the study; Group B was treated with Chloramphenicol at the dose rate of $25 \mathrm{mg} / \mathrm{kg}$ body weight per os for 20 days; while Group $\mathrm{C}$ was treated for 25 days. Semen used in this study was obtained from the caudal epididymides while morphological aberrations were determined from spermatozoa counted after stained with Wells and Awa stain. Results of the spermiogram showed that the volume was decreasing as the prolonged dosage of chloramphenicol increases. The percentage motility in Group A ( $89.0+2.45 \%)$, differed significantly $(\mathrm{p}<0.05)$ when compared to Group B $(72.0+3.74 \%)$ and Group C $(66.0+2.45 \%)$. The same pattern is observed in percentage liveability, morphological aberration and sperm concentration. This indicates that prolonged dosage of chloramphenicol will cause infertility in male animals. It is therefore concluded and recommended that prolonged dosage of chloramphenicol can cause infertility and or sterility. So it should not be used in male animals meant for mature breeding and artificial insemination programme.

KEY WORDS: Chloramphenicol; Breeding; Spermatozoa; Wistar rats; Infertility.

\section{INTRODUCTION}

Chloramphenicol is an antibiotic with a chemical formula $\mathrm{C}_{11} \mathrm{H}_{12} \mathrm{C}_{12} \mathrm{~N}_{2} \mathrm{O}_{5}$, derived from the bacterium Streptomyces venezuelae or produced synthetically and effective against a broad spectrum of microorganisms.

Chloramphenicol is a highly effective and welltolerated broad-spectrum antibiotic. However, it does have several features that demand careful use in companion animals and that have led to prohibition of its use in foodproducing animals in several countries, including the USA and Canada (Kahn, 2005). Chloramphenicol is used extensively in non-industrialised countries for life threatening infections because it is cheap and effective despite its known haemotoxicity and linkage to fatal aplastic anaemia (Saba et al., 2000).

Epididymal transit is the movement of the sperm cells from caput (head) through corpus (body) to tail of the epididymis. Sperm cells stored in the caudal epididymis at the end of spermatogenesis can be influenced by age, nutrition, drug, temperature and successive ejaculations (Oyeyemi et al., 2002; Oyeyemi et al., 2006). The normal sperm cells of Wistar rats consist of a hook shaped head (question mark shape), a thin neck, mid-piece and a long tail. It is only in rats and mice that the heads of spermatozoa terminate in a distinct "hook" shape (Garner \& Hafez, 1993).

Blood is composed of cells and plasma. Plasma is the liquid component of blood within which the cell and colloids are suspended and other transported materials are dissolved (Reece, 1997). Plasma is yellow to colourless, depending on the quantity, the species of animal and the animals' diet. Blood volume and plasma volume can be influenced by weight of the animal, nutrition, drugs and excessive exercise. The functions of blood are so numerous 
that to list each function individually would require a rather extensive enumeration. The functions of blood can, however be summarized as being within the following categories: respiratory, excretory, nutritive, thermal regulation of the body, protective, and regulatory. Blood affects these functions through its ability to transport heat, nutrients, waste products of metabolism, products of internal secretion (hormones), and immune bodies from one portion of the body to another (Beames et al., 1971).

Semen is the complete discharge of the male during normal ejaculation. It has two major components; the spermatozoa or cellular elements and the cellular plasma or liquid portion. Sperm are produced in the seminiferous tubules of the testes, which are controlled by hormones from the anterior pituitary gland (Garner, 1987). Semen should have a relatively uniform opaque appearance indicative of high sperm cell concentration (Hafez, 1993). The total sperm producing capacity of the male is determined genetically but there are many factors, which determine what portion of the germ cells that are actually delivered for reproductive purpose. The important external or environmental factors affecting sperm production and development include temperature, photoperiod, humidity, nutrition, drugs, stress and toxic substances (Hafez; Farombi et al., 2007; Oyeyemi et al., 2006).

\section{MATERIAL AND METHOD}

Fifteen albino rats (Wistar Strain) used in this study were housed in the Experimental Animal Unit (EAU) of the Faculty of Veterinary Medicine, University of Ibadan, Nigeria.

There were three groups of five rats each kept in three cages measuring about 18 by 12 inches under the same environmental conditions. The rats were allowed a period of one week to stabilize with their new environment different from where they were bought.

The rats were fed ad libitum with commercially prepared feed and given fresh water. They were kept in cages and their faeces cleaned out twice a week. The feeds and water were provided in earthen troughs.

The rats were in groups $\mathrm{A}, \mathrm{B}$ and $\mathrm{C}$ of 5 rats each. Group A served as control of the study; Group B was treated with chloramphenicol for 20 days; while Group $\mathrm{C}$ was treated for 25 days. All the rats were marked for proper identification.
Blood collection. Blood was collected from each of the rats from the orbital sinus called the infra orbital lateral canthus method. This was done using heparinised capillary tubes, a glass chamber, anaesthetic ether, cotton wool, and $2 \mathrm{ml}$ heparinized sample bottles and a recovery cage. Blood analysis was carried out by method of Beames et al.

Drug administration. The rats in groups $\mathrm{B}$ and $\mathrm{C}$ were allowed to stabilize and chloramphenicol palmitate suspension (Chloraf®) administered to rats of about 14 weeks of age at the dose rate of $25 \mathrm{mg} / \mathrm{kg}$ body weight per os for 20 and 25 days respectively. The rats in Group A, which was the control group, were left without the drug.

Semen collection. The rats were put into a glass chamber containing cotton wool soaked in chloroform and allowed to lose consciousness. The testicles were then removed through a lower abdominal incision and testes were then separated from the epididymis. The right and left epididymis were trimmed off the body of the testes and semen samples were collected from the tail of the epididymis through an incision made with a scalpel blade. Sperm cells were sucked into a Pasteur pipette from the caudal epididymis. The incisions were also flushed with $2-3$ drops of $2.9 \%$ buffered sodium citrate kept at body temperature.

Semen analysis. The semen samples were analysed by method described by Zemjanis (1977).

\section{RESULTS}

The spermatozoa characteristics of Wistar rats in Groups A (control), B treated with chloramphenicol for 20 days and $\mathrm{C}$ treated with chloramphenicol for 25 days are as presented in Table I.

Motility in the control experiment (Group A) was $89.0 \pm 2.45 \%$, which is higher than Group B $(72.0 \pm 3.74 \%)$ and Group C $(66.0 \pm 2.45 \%)$. The difference between Group A and Groups B and C differ significantly $(\mathrm{p}<0.05)$

Group A without chloramphenicol treatment had superior value of percentage live spermatozoa $(95.2 \pm 1.46 \%)$ when compared with Group B $(85.0 \pm 2.24 \%)$ and Group C $(83.0 \pm 3.74 \%)$. Group A is significantly higher $(\mathrm{p}<0.05)$ than Groups B and C, while the differences between Groups $B$ and $C$ is not significant ( $p>0.05)$. The volume of the semen decreased as the days of treatment increased, the longer the treatment, the lower the volume of the semen. 
OYEYEMI, M. O. \& ADENIJI, D. A. Morphological characteristics and haematological studies in Wistar rats subjected to prolonged treatment of chloramphenicol. Int. J. Morphol., 27(1):7-11, 2009.

Table I. Spermatozoa characteristics of Wistar rats treated with chloramphenicol.

\begin{tabular}{lcccc}
\hline Groups & Motility $(\boldsymbol{\%})$ & Live/dead liveability & Volume & Sperm concentration $\mathbf{x 1 0}^{\mathbf{6}} \mathbf{\text { cell}} / \mathbf{m l}$ \\
\hline A (Control) & $89.0+2.45$ & $95.2+1.46$ & $0.16+0.02$ & $82.0+2.70$ \\
B (20 days) & $72.0 \pm 3.74$ & $85.0 \pm 2.24$ & $0.14 \pm 0.02$ & $54.8 \pm 2.22$ \\
C (25 days) & $66.0 \pm 2.45$ & $83.0 \pm 3.74$ & $0.12 \pm 0.02$ & $54.0 \pm 3.21$ \\
\hline
\end{tabular}

Table II. Haematological results of Wistar rats treated with chloramphenicol.

\begin{tabular}{lccccl}
\hline Groups & PCV & \multicolumn{1}{c}{ RBC } & WBC & Neutrophils & Lymphocytes \\
\hline A1 & $31.60+4.35$ & $11.43+1.95$ & $19.40+4.57$ & $61.40+6.78$ & $38.60+6.78$ \\
A2 & $39.80 \pm 1.71$ & $10.73 \pm 1.37$ & $18.72 \pm 2.62$ & $29.40 \pm 3.19$ & $70.60 \pm 3.19$ \\
B1 & $37.80 \pm 1.24$ & $13.51 \pm 0.83$ & $23.96 \pm 3.38$ & $65.20 \pm 3.73$ & $38.80 \pm 1.83$ \\
B2 & $45.60+1.12$ & $9.62+0.70$ & $17.76+2.90$ & $43.20+7.60$ & $56.80+7.60$ \\
C1 & $26.20+3.15$ & $9.38+0.97$ & $15.52+2.17$ & $41.00+5.34$ & $59.00+5.34$ \\
C2 & $39.40+1.17$ & $9.94+0.89$ & $18.84+2.21$ & $37.40+3.50$ & $62.60+3.50$ \\
\hline
\end{tabular}

Table III. Morphological aberration in Control and Treated Groups.

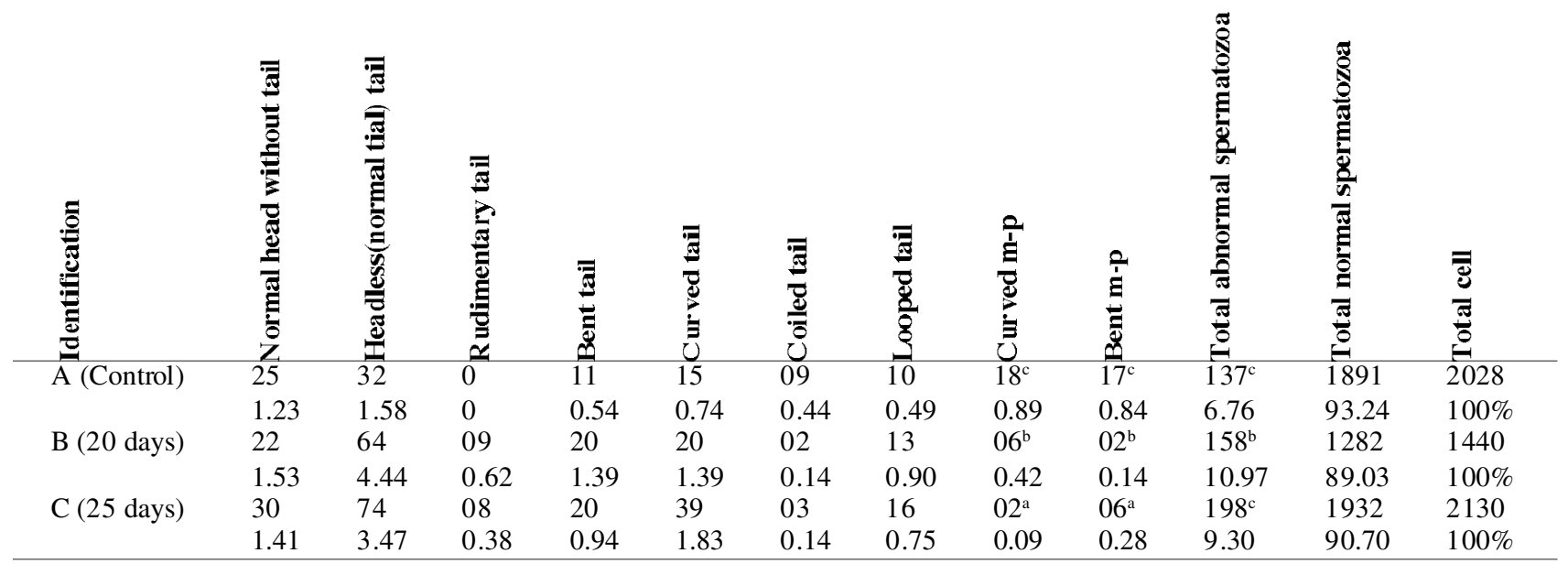

Semen concentration: The values of semen concentration $\left(\mathrm{x} 10^{6} \mathrm{cell} / \mathrm{ml}\right)$ in Group A $(82.0 \pm 2.70)$ is significantly higher $(\mathrm{p}<0.05)$ than Group B $(54.8 \pm 2.22)$ and Group C $(54.0 \pm 3.21)$. There was a decrease in the value of semen concentration as the numbers of days of treatment were increased.

Haematological results of this study are as presented in Table II. It was observed that pre - experiment values of PCV in Group A - C, were significantly lower $(\mathrm{p}<0.05)$. The values of RBC and WBC did not present a regular pattern. While the values of lymphocytes in pre-experiment in Groups A1 - C1 were lower than experiment values of Groups A2 - C2. The differences in the values of Groups $\mathrm{A} 1$ and $\mathrm{A} 2$ and $\mathrm{B} 1$ and B2 differed significantly $(\mathrm{p}<0.05)$ while Groups C1 and C2 value is not significant ( $\mathrm{p}>0.05)$.

The morphological aberrations observed in this study indicated that Group A had a total abnormal spermatozoon of 137, Group B had 158 and Group C had 198. The abnormal spermatozoa in Group $\mathrm{C}$ is significantly higher $(\mathrm{p}<0.05)$ than Groups B and A. The treatment groups had higher morphological aberrations than untreated group as presented in Table III. 


\section{DISCUSSION}

In this study, the volume of the semen was decreasing as the days of treatment with chloramphenicol are prolonged. The unidirectional progressive movement (motility) decreased as the treatment prolongs. The percentage liveability indicated that the treatment adversely affected the liveability potential of the spermatozoa. The volume, motility and liveability are parameters in the determination of viability and fertility in the male animals. It is now observed from this study that prolonged treatment of chloramphenicol will cause infertility when used at $25 \mathrm{mg} / \mathrm{kgbw}$ for 20 to 25 days. This observation is similar to reports of Oyeyemi \& Okediran (2007), Hughes \& Varley (1980).

The decrease noticed/observed as per the days of treatment in semen concentration indicated that prolonged treatment of chloramphenicol has adverse effect on fertility potential of the male animal. This indicates that there is possibility of lower fertility rate by the reason of the number of spermatozoa available at the time of copulation or insemination. This study indicated that capacity of the testes decreases with increasing the days of treatment to produce sperm cells (spermatogenesis). These finding are similar to reports of Paufler et al. (1969), Oyeyemi et al. (2002) and Morris et al. (1979).

The haematogical results indicated that experimen- tal values were superior to the pre - experimental values indicating a better performance. This may be due to treatment effect on possible ailment in the animal before the experiment (Beames et al.). It is also known that chloramphenicol produces a non - regenerative anaemia due to bone marrow depression and also hepatoxic effects (Saba et al.; Plumb, 1999).

In general, total abnormalities in Group A is significantly lower $\mathrm{p}<0.05$ than in Group B which in turn lower $(\mathrm{p}<0.05)$ than Group C. This indicated that prolonged dosage affects the normal structure of the spermatozoa ranging from curved tail to looped tail.

The study revealed that patterns of morphological aberration follows the pattern of decrease of volume, motility and liveability - indicating that prolonged dosage of chloramphenicol can cause infertility and or sterility (Zemjanis, 1977).

In conclusion, since the adverse effects of prolonged dosage affect the fertility potential of the male rats, it is therefore concluded and recommended that male animals meant for breeding or to be used in artificial insemination programme should not be subjected to prolonged dosage of chloramphenicol.

OYEYEMI, M. O. \& ADENIJI, D. A. Características morfológicas y estudios hematológicos en ratas Wistar sometidas a un tratamiento prolongado de cloranfenicol. Int. J. Morphol., 27(1):7-11, 2008.

RESUMEN: Fueron estudiadas las características morfológicas y hematológicas de 15 ratas albinas Wistar, macho, entre 12 y 14 semanas y con un peso corporal de 150 - 180g. Las ratas fueron alimentadas con pellet preparado comercialmente y con agua fresca ad libitum. Las ratas fueron divididas en tres grupos de 5 ejemplares cada uno. El Grupo A sirvió como control; Grupo B fue tratado con cloranfenicol en dosis de $25 \mathrm{mg} / \mathrm{kg}$ de peso corporal durante 20 días, mientras que el Grupo C recibió este tratamiento durante 25 días. El esperma utilizado en este estudio se obtuvo desde la cauda del epidídimo, donde las aberraciones morfológicas fueron determinadas a partir del conteo de espermatozoides, después de ser teñidos con la tinción de Wells y Awa. Los resultados del espermiograma puso de manifiesto que el volumen fue disminuyendo a medida que la dosis de cloranfenicol aumentaba. El porcentaje de motilidad en el grupo A $(89,0 \pm 2,45 \%)$, fue diferente significativamente $(\mathrm{p}<0,05)$ en comparación con el Grupo B $(72,0 \pm 3,74 \%)$ y Grupo C $(66,0 \pm 2,45 \%)$. El mismo patrón se observó en los porcentaje de habitabilidad, aberración morfológica y la concentración de espermatozoides. Esto indica que la prolongación de la dosis de cloranfenicol puede causar infertilidad en los animales machos. Por lo tanto, se concluye y recomienda que una prolongada dosis de cloranfenicol puede causar infertilidad o esterilidad, así que no debe utilizarse en animales machos destinados a la cría y en los programas de inseminación artificial.

PALABRAS CLAVE: Cloranfenicol; Crianza; Espermatozoide; Ratas Wistar; Infertilidad.

\section{REFERENCES}

Beames, C. G.; Cardielh, P. T. \& Newcomer, W. S. Textbook of Veterinary Physiology. Philadelphia, Lea and Febiger, 1971.
Farombi, E. O.; Abarikwu, S. O. \& Oyeyemi, M. O. Culcumin and Kolaviron Ameliorate Di-nButylphthalate-induced Testicular Damage in Rats. Basic 
and Clinical Pharmacology and Toxicology, 100:43-8, 2007.

Garner, D. L. Spermatozoa. In: Reproduction in Farm Animals. Edited by Hafez, E. S. E. Philadelphia, Lea and Febriger, 1987.

Garner, D. L. \& Hafez, E. S. E. Spermatozoa and seminal plasma. In: Reproduction in Farm Animal. $6^{\text {th }}$ edn. Edited by: Hafez, E. S. E. Philadelphia, Lea and Febiger, 1993. pp.165-87.

Hafez, E. S. E. Reproduction in farm animals. $6^{\text {th. }}$ ed. Philadelphia, Lea and Febiger Publishers, 1993. p.405.

Hughes, P. E. \& Varley, M. A. Factors affecting male fertility. In: Reproduction in the pig. London, Ed. Butterwarths, 1980. p. 191

Kahn, M. C. Chloramphenicol and Congeners. In: The Merck Veterinary Manual. $9^{\text {th }}$ ed. New York, Merck \& Co., 2005.

Morris, O. L.; Smith, M. F.; Parrish, W. R.; William, J. D. \& Wilbank, J. N. The effect of scrotal circumference, libido and semen quality on fertility of American Brahaman and Santa Certudies Bull. Proceeding of Animal Management of the Society for Theriogenology, Oklahoma City, 1979.

Oyeyemi, M. O.; Oke, A. Olusola; Ajala, O. Oluwatoyin \& Idehen, C. O. Differences in testicular parameters and morphological characteristics of spermatozoa as related to age of West African Dwarf bucks. Tropical Journal Animals Science, 5 (1):99-107, 2002.

Oyeyemi, M. O. \& Okediran, B. S. Testicular parameters and sperm morphology of chinchilla rabbit fed with different planes of soymeal. Int. J. Morphol., 25(1):13944, 2007.

Oyeyemi, M. O.; Towobola, B. A. \& Ola-Davies, O. E. The Reproductive implication of Clomiphene citrate on sperm cells during the epididymal transit of spermatozoa in male Wistar rats. Folia Veterinaria, 50(3):131-3, 2006.

Paufler, S.; Van Vleck, L. D. \& Foote, R. H. Estimation of testicular size in live rabbits. Int. J. Fertil., 14(2):18891, 1969.

Plumb, D. C. Veterinary Drug Handbook. $3^{\text {rd }}$ ed. Iowa State, University Press, 1999. pp.122-5.
Reece, W. O. Physiology of Domestic Animals. $2^{\text {nd }}$ ed. Baltimore, Lippincott Williams \& Wilkins, 1997. pp.1249.

Saba, A. B.; Ola-Davies, O. E.; Oyeyemi, M. O. \& Ajala, O. $\mathrm{O}$. The toxic effects of prolonged administration of chloramphenicol on the liver and kidney of rats. Afr. $J$. Biomed. Res., 3:133-7, 2000.

Zemjanis, R. Diagnostic and Therapeutic Techniques in Animal Reproduction. Baltimore, Williams and Wilkins Company, 1977. pp.139-54.

Correspondence to:

Dr. Oyeyemi, Matthew Olugbenga Ph. D.

Department of Veterinary Surgery and Reproduction,

Faculty of Veterinary Medicine

University of Ibadan

NIGERIA

Phone: +234803 8059952

Email: mo.oyeyemi@mail.ui.edu.ng oluoyeyemi03@yahoo.com

Received: 09-10-2007

Accepted: 20-06-2008 
